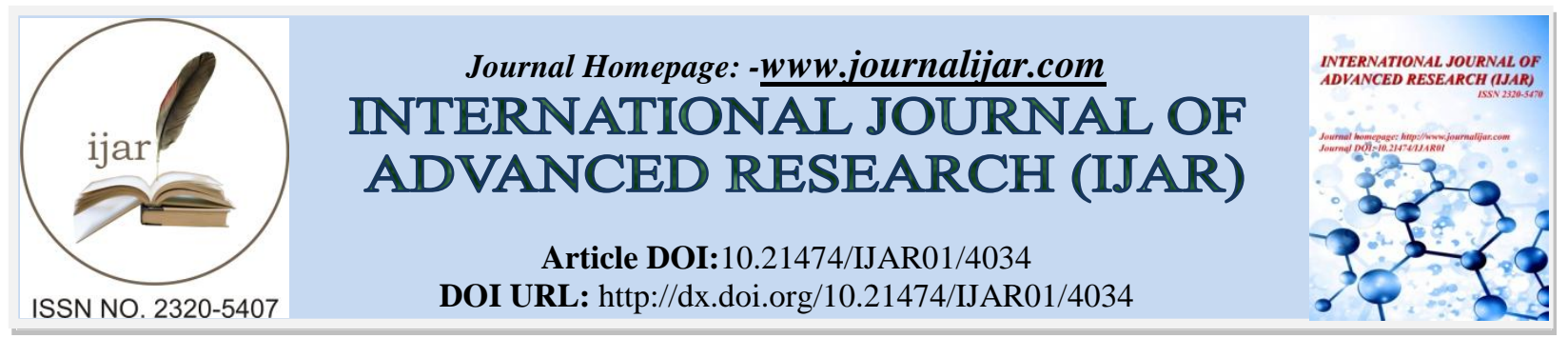

RESEARCH ARTICLE

\title{
ISOLATION AND CHARACTERIZATION OF ACTIVE CONSTITUENT AND MICROSCOPIC STUDIES OF STEM AND LEAVE OFBOERHAAVIA DIFFUSA LINN.
}

Dr. P. Venkatesh ${ }^{*}$ and Dr. D. HepcyKalarani.

Department of Pharmaceutical Chemistry, Jagan's College of Pharmacy, Nellore-524 346. Andhra Pradesh. India.

\section{Manuscript Info}

Manuscript History

Received: 26 February 2017

Final Accepted: 24 March 2017

Published: April 2017

Key words:-

EEBD, Column chromatography, Spectroscopy, Alkyl flavone, Microscopy.

\section{Abstract}

Active constituent was isolated from an Ethanolic extract of stem and leaves of Boerhaavia Diffusa (EEBD) by using Column Chromatography. Characterization of an isolated compound was done by various spectroscopic studies such as Infrared (IR) spectra, Nuclear Magnetic Resonance (NMR) spectra and Mass Spectral studies. Interpretation of the spectra obtained suggested that the isolated compound may be Alkyl flavone. Further the plant parts were subjected to microscopic studies.

Copy Right, IJAR, 2017,. All rights reserved.

\section{Introduction:-}

Boerhaavia Diffusa Linn is commonly called as Hog Weed in English, Mukaratte-Kirei intamil and as Punarnava in Hindi (Edwin et al., 2009). It consists of fresh as well as dried herb Boerhaavia Diffusa linn and belongs to the family Nyctaginaceae. The plant is found throughout India, Sri Lanka, China, Malaysia and Africa (Sanjay., 2008, Kokateet al., 2012)). The plant revives every year during rainy season that is why it is named as Punarva (again fresh). Leaves are green on upper surface and whitish on lower surface. Leaves are opposite, ovate-oblong, apex rounded or slightly pointed, base subcordate, glabrous on upper. Margin is entire. Stem is greenish purple in color, cylindrical, stiff and thick at the nodes. They are branched and about $1 \mathrm{~m}$ in length. Stems are light-reddish brown above and pale greenish below (Kumar., 2010, Vinod., 2006).

Fig.1:-Boerhaavia Diffusa Linn.

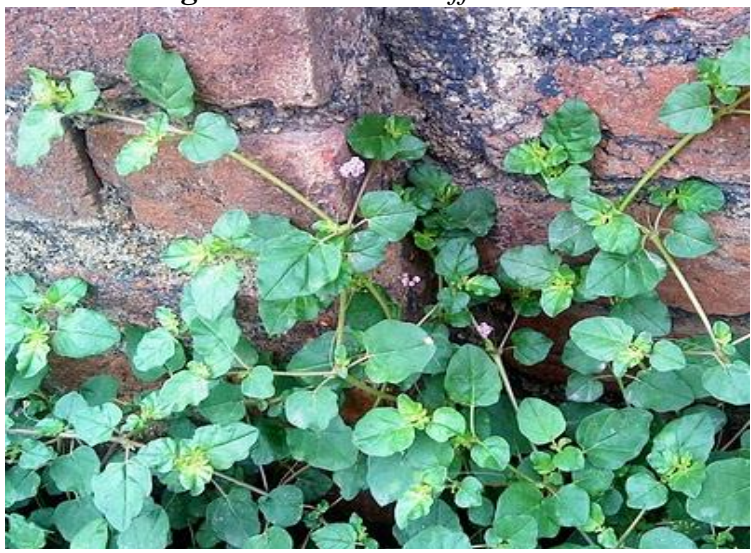

Corresponding Author:-Dr.P.Venkatesh.

Address:-Department of Pharmaceutical Chemistry, Jagan's College of Pharmacy, Nellore-524 346.

Andhra Pradesh. India. 


\section{Materials And Methods:-}

Collection and authentication of the plants:-

The stem and leaves of Boerhaavia diffusa were collected from Sri Venkateswara University campus, Tirumala gardens of Chittoor district of Andhra Pradesh, India and the same were authentified by Assistant Professor, Dr.K.MadhavaChetty, Department of Botany, S.V.University, Tirupati, AP. Voucher specimens were deposited at department of pharmacognosy for further reference.

\section{Preparation of Extracts:-}

The shade dried plant materials were reduced to moderately coarse powder and extracted successively with various solvents of increasing polarity using Soxhlet apparatus. The extraction was carried out until the extractive becomes colorless. The solvent was completely removed from the marc in each case before the next extraction was carried out. The solvents were recovered from their extract by distillation under reduced pressure. The dried extracts thus obtained were kept in a desiccator and was used for further experiments (Mukherjee., 2010). Further the extract was subjected to preliminary phytochemical screening for the identification of the presence or absence of various constituents such as phytosterols, triterpenoids, carbohydrates, glycosides, alkaloids, saponins, tannins/phenols and flavonoids (Niren et al., 2009, Khandelwal., 2008).

\section{Isolation and characterization of chemical constituent:-}

$35 \mathrm{gm}$ of the crude mixture of EEBD was mixed with $110 \mathrm{gm}$ of silica gel (60-120 mesh) to made admixture and the admixture was packed in a 2.4 diameter column with hexane. The column was eluted with increasing solvent polarity from hexane to ethyl acetate.

The column was first eluted with n-hexane and then n-hexane with 5\% increments of ethyl acetate. For each eluent mixture more than $500 \mathrm{ml}$ of solvent was used. The fractions were collected in glass beakers. Collected fractions were concentrated using Bruchi-114 Rota vapor. Chemical tests and TLC were performed to analyze the fractions. These fractions were dried. The mobile phase in TLC used was ethyl acetate and hexane. Different ratios of ethyl acetate and hexane were tried and finally the product obtained in 16-24 fractions with the TLC mobile phase ethyl acetate: hexane $(2: 8)$ ratio glows at $365 \mathrm{~nm}$.

Table1:- Column elution - EEBD.

\begin{tabular}{|c|c|c|c|}
\hline S.No & Number of fractions & Percentage of solvents & Volume of solvent \\
\hline 1 & $1-8$ & $100 \%$ Hexane & $600 \mathrm{ml}$ \\
\hline 2 & $9-15$ & $5 \%$ Ethyl acetate $: 95 \%$ hexane & $500 \mathrm{ml}$ \\
\hline 3 & $16-24$ & $10 \%$ Ethyl acetate $: 90 \%$ hexane & $600 \mathrm{ml}$ \\
\hline
\end{tabular}

Constituent isolated from EEBD was subjected to IR, ${ }^{\mathrm{H}} \mathrm{NMR},{ }^{13 \mathrm{C}} \mathrm{NMR}$ and Mass spectral analysis for its characterization.

\section{Microscopic studies of plant parts:-}

The collected plant parts were fixed in FAA (Formalin 5ml + Acetic acid 5ml + 70\% Ethyl alcohol 90ml). After 24 hrs of fixing, the specimens were dehydrated with graded series of tertiary butyl alcohol (TBA). Infiltration of the specimens was carried by gradual addition of paraffin wax (melting point $58-60^{\circ} \mathrm{C}$ ) until TBA solution attained super saturation. The specimens were cast into paraffin blocks.

The paraffin embedded specimens were sectioned with the help of Rotary Microtome. Dewaxing of the sections was done by customary procedure. The sections were stained with toluidine blue. Since toluidine blue is a polychromatic stain. The staining results were remarkably good and some cytochemical reactions were also obtained. The dye rendered pink color to the cellulose walls, blue to the lignified cells, dark green to suberin, violet to the mucilage, blue to the protein bodies etc. Where ever necessary sections were also stained with safranin and fast-green and iodine potassium iodide (for starch) (Easu., 1964, Gamble., 1935).

For studying the stomatal morphology, venation pattern and trichome distribution, paradermal sections (sections taken parallel to the surface of leaf) as well as clearing of leaf with $5 \%$ sodium hydroxide or epidermal peeling by partial maceration employing Jeffrey's maceration fluid were prepared. Glycerine mounted temporary preparations were made for macerated/cleared materials. Powdered materials of different parts were cleared with sodium hydroxide and mounted in glycerine medium after staining. Different cell component were studied and measured. 
Photographs of different magnifications were taken with Nikon lab photo microscopic unit. For normal observations bright field was used. For the study of crystals, starch grains and lignified cells, polarized light was employed. Since these structures have birefringent property, under polarized light they appear bright against dark background. Magnifications of the figures are indicated by the scale-bars (Yoga., 2000, Medcalfeet al., 1979).

\section{Results and Discussion:-}

Spectral analysis of isolated constituent from EEBD:-

IR spectra:-

The IR absorption of EEBD showed the absorption peaks of $2925 \mathrm{~cm}^{-1}$ (aromatic ring), $2858 \mathrm{~cm}^{-1}$ (alkanes), 1723 $\mathrm{cm}^{-1}$ (ketone) and other absorption peaks include $1278 \mathrm{~cm}^{-1}, 1072 \mathrm{~cm}^{-1}$ for ether and alkane bending respectively.

Fig2:- IR Spectrum

$\begin{array}{ll}{ }_{\text {NMMR spectra }} & \\ \mathrm{R}^{\mathrm{C}} \mathrm{CH}_{3} & : \delta 0.9 \\ \text { Ketone } & : \delta 2.0 \\ \text { Aromatic -CH } & : \delta 2.3 \\ \text { Aromatic -O-CH } & : \delta 4.1 \\ \text { Aromatic -H } & : \delta 7.6\end{array}$

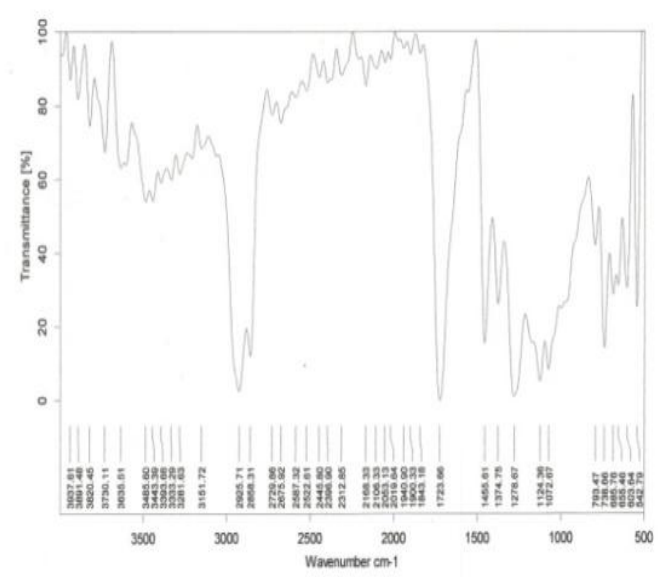

Fig3:- ${ }^{\mathrm{H}} \mathrm{NMR}$ spectrum.

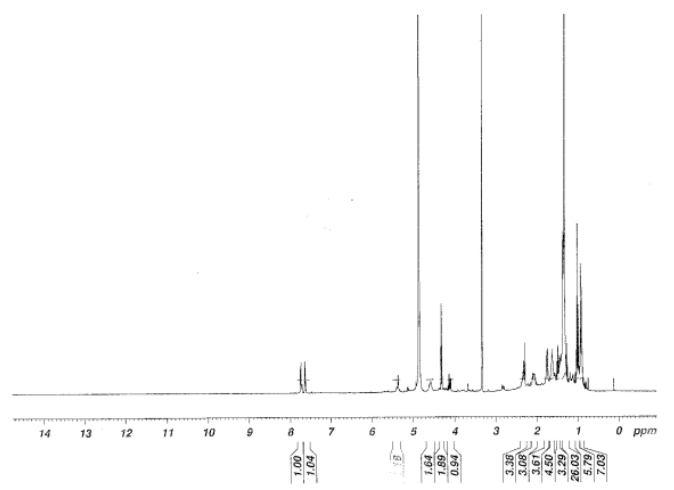

\section{${ }^{13}$ C NMR spectra}

The ${ }^{13} \mathrm{C}$ NMR (MeOD, $125 \mathrm{MH}_{2}$ ) of EEBD has given the signals at 130.9, $128.4(\mathrm{C}-5,6,7,8,9,10,11,12,13,14,15,16)$, 57.65 (C-24), 28, 30,31 (C-19,20), 12,13,18 (C-17,22,25). 
Fig4:- ${ }^{13}$ C NMR spectrum

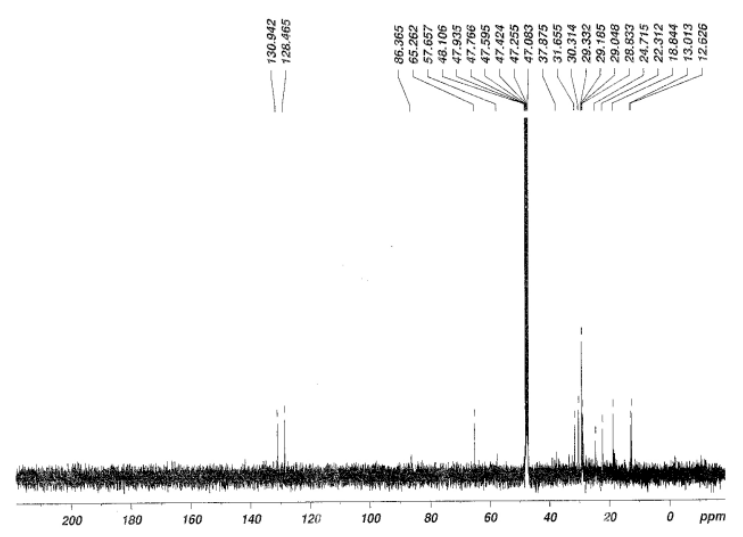

Mass spectra:-

Molecular ion peak of EEBD was observed at 335 in the mass spectrum. The fragmentations were seen at $\mathrm{m} / \mathrm{z} 267$, 123,71 and 41 .

Fig5:- Mass spectrum.

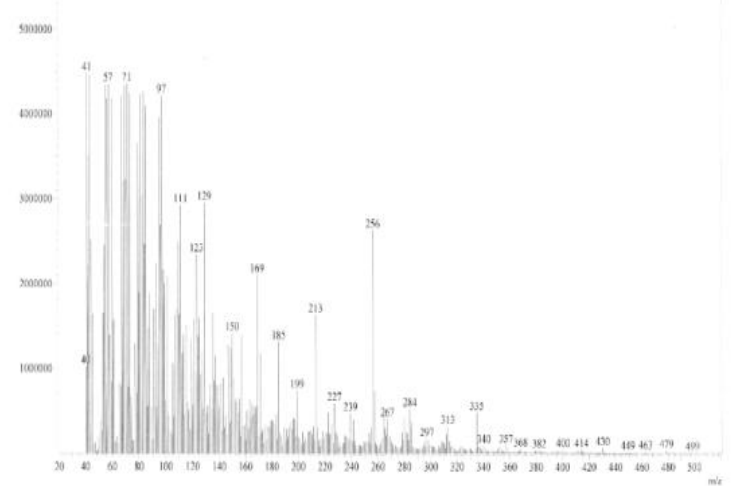

All the recorded data such as spectral analysis suggested that the isolated constituent from EEBD is "alkyl flavone"

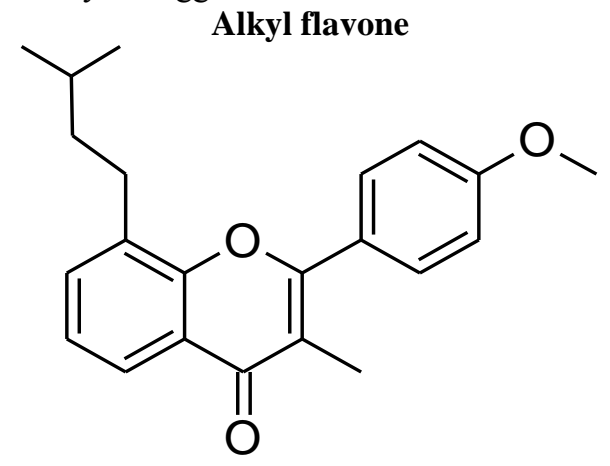

\section{Structure of isolated constituent of Boerhaavia diffusa}

\section{Microscopic studies of stem and leaves of Boerhaavia Diffusa}

Anatomy of stem:-

The stem measuring $1.7 \mathrm{~mm}$ was studied. The stem exhibits unusual structure of anomalous secondary growth. It consists of central group of discrete vascular bundles called medullary bundles. The medullary bundles are surrounded by a thick continuous secondary xylem. 
Fig 6:- T.S of stem - entire view.

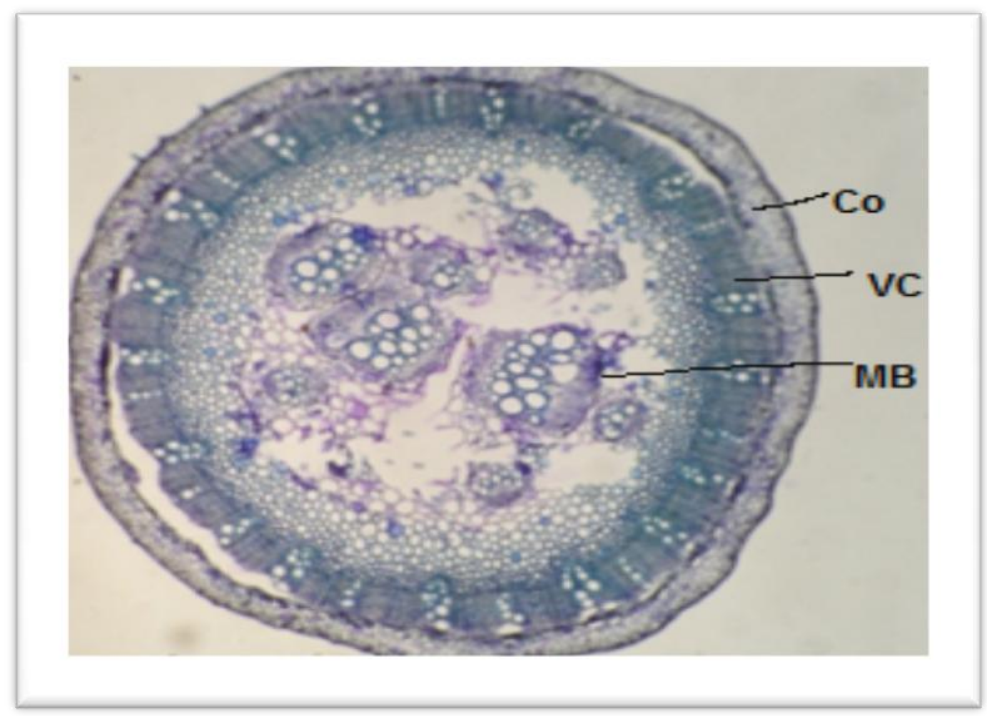

VI-Vein islets, VT-Vein termination, Ra-Raphide, Co-Cortex, VC-Vascular cylinder, MB-Medullary bundle

Fig.7:- T.S of stem - Half portion enlarged.

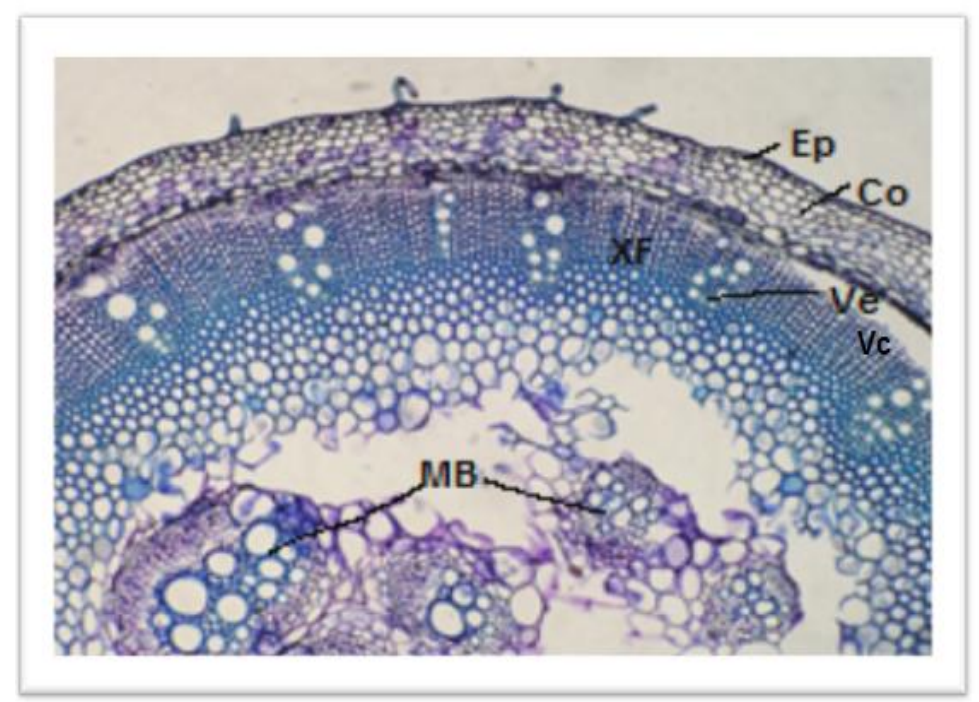

The stem consists of a thin epidermal layer of rectangular cells with prominent cuticle. The cortex consists of about six layers of rectangular thin walled parenchymatous cells. The inner most layer of the cortex includes slightly dilated rectangular cells.

\section{Medullary bundle:-}

The medullary bundles include two larger central bundles and about six smaller outer bundles. All medullary bundles have primary xylem and limited amount of secondary xylem. The cambium within the bundles functions for short period and produces secondary xylem and secondary phloem. Then the cambium activity stops. A new cambium originates from the outer part of cortical zones which produces new secondary xylem and secondary phloem. 
Fig8:- T.S of stem - A sector enlarged.

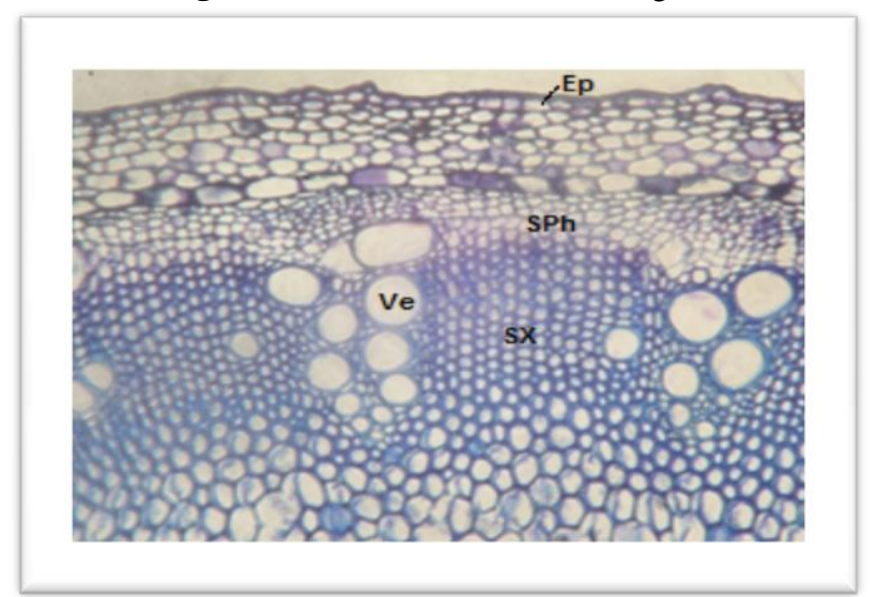

Ep-Epidermis, Co-Cortex, MB-Medullary bundle, VC-Vascular cylinder, Ve-Vessel, XF-Xylem fiber, SPhSecondary phloem, SX-Secondary xylem

Fig.9:- Structure of the vascular bundle.

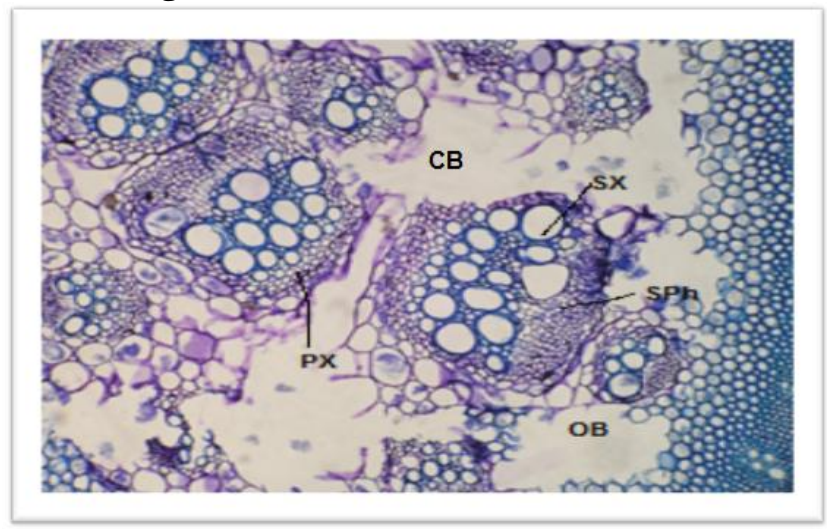

The secondary xylem consists of thick cylindrical xylem fibres in which radial groups of wide circular solitary vessels occur. The vessels towards the center are small measuring $10 \mu \mathrm{m}$ in diameter. Those towards the peripheral region are $50 \mu \mathrm{m}$ in diameter. The medullary bundles have dense cluster of wide circular, thick walled vessels. The secondary xylem vessels are $60 \mu \mathrm{m}$ in diameter.

Fig 10:- Vascular bundle enlarged

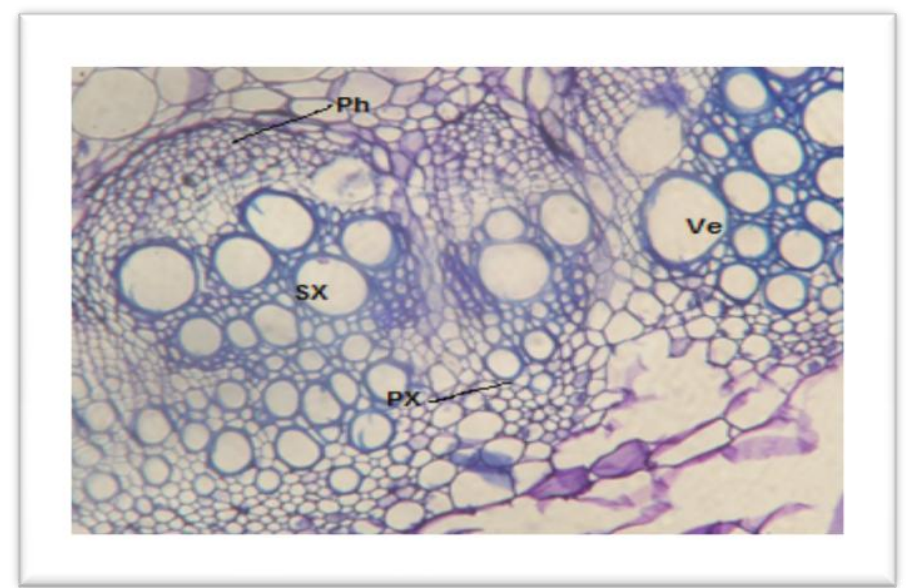

CB-Central bundle, OB-Outer bundle, SPh-Secondary phloem, SX-Secondary xylem, PX-Primary xylem, Ph-Phloem, Ve-Vessel 


\section{Anatomy of leaf:-}

The leaf is dorsi ventral with less prominent midrib and thick lamina.

\section{Midrib:-}

The midrib is $500 \mu \mathrm{m}$ thick, has a shallow concavity on the abaxial side and thin semicircular abaxial part. The epidermis of the midrib consists of circular thick walled cells. The ground tissue includes angular, compact parenchyma cells.

Fig11:- T.S of leaf

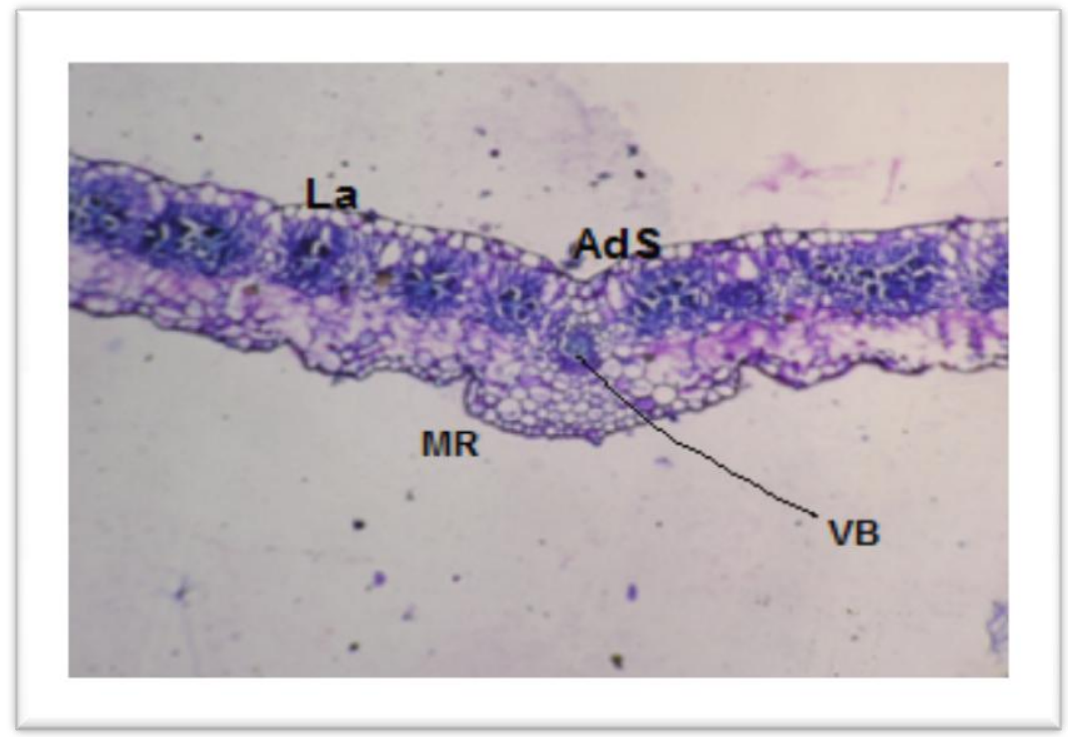

\section{Vascular strand:-}

Thevascular strand is single, small, top-shaped and collateral. It includes a few short, narrow lines of xylem elements and a small cluster of phloem elements. There is a layer of bundle sheeth cells which is extended in the adaxial part.

Fig12:- T.S of midrib.

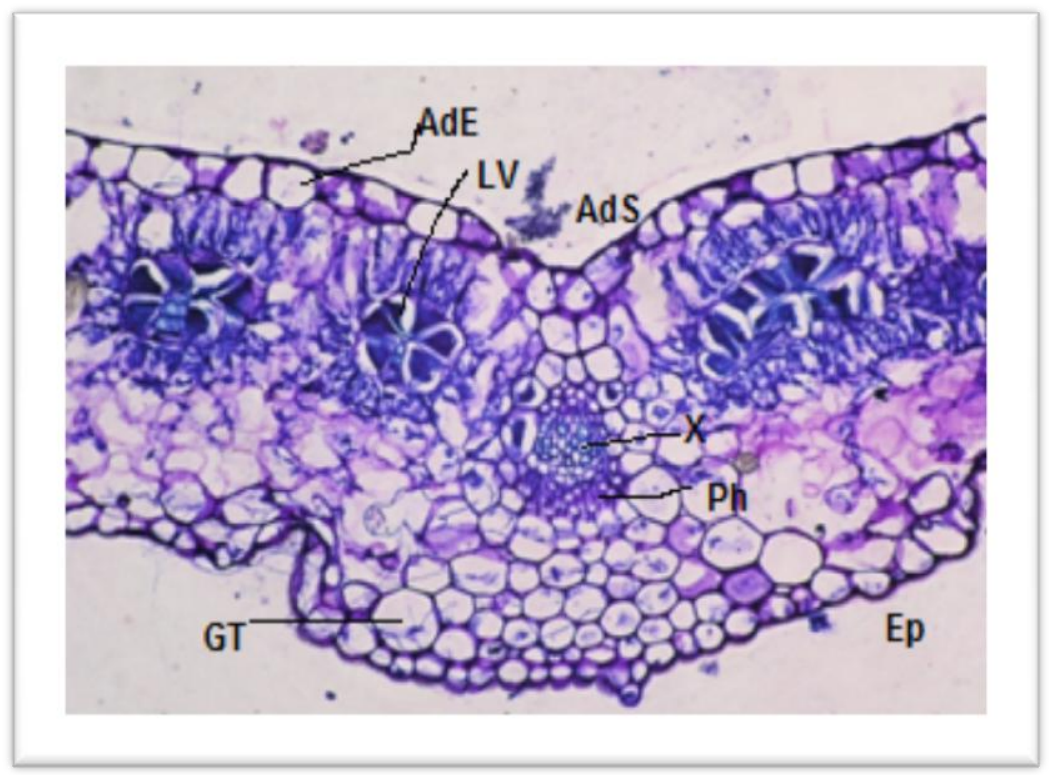

La-Lamina, AdS-Adaxial side, VB-Vascular bundle, MR-Midrib, AdE-Adaxial epidermis, LV-Lateral vein, X-Xylem, Ph-Phloem, GT-Ground tissue, Ep-Epidermis 


\section{Lamina:-}

The lamina is $470 \mu \mathrm{m}$ thick. The lamina is amphistomatic, the epidermal layer is thick and comprises of fairly thick cells. The cuticle is thin. The mesophyll tissue consists of a single adaxial row of short cylindrical palisade cells and lobed loosely arranged spongy parenchyma cells. The upper median part of the lamina consist circular lateral veins. The vein has a small group of xylem and phloem elements surrounded by a rosette of kranz-cells with prominent chloroplasts.

Fig13:- T.S of Lamina

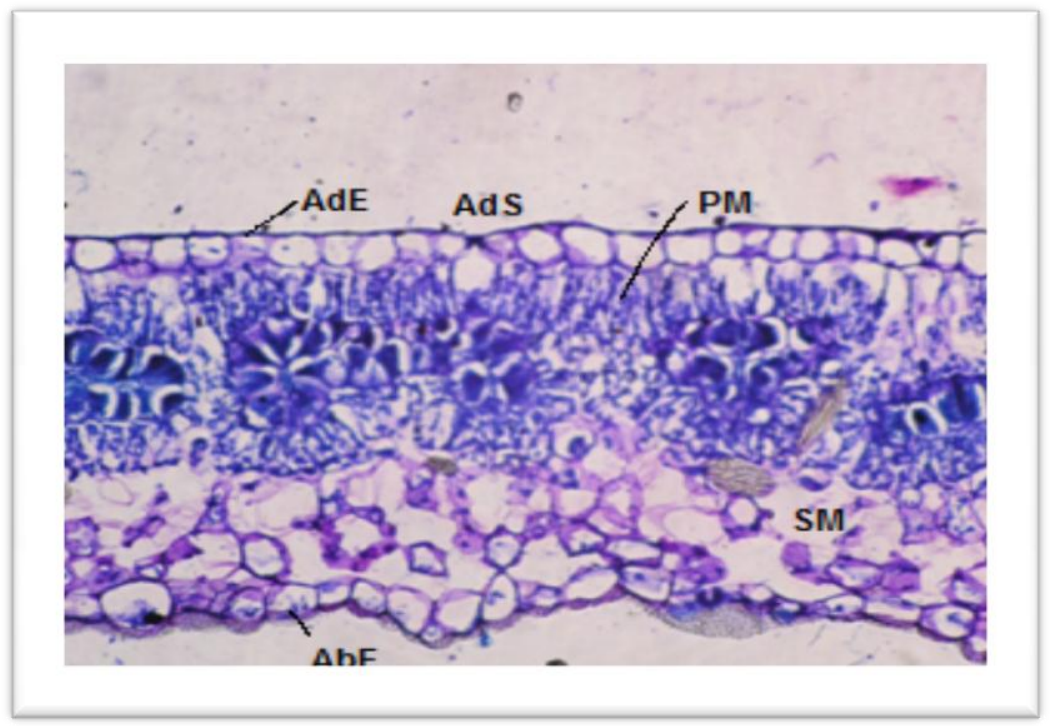

Fig14:- T.S of Lamina with Kranz bundle sheath cells.

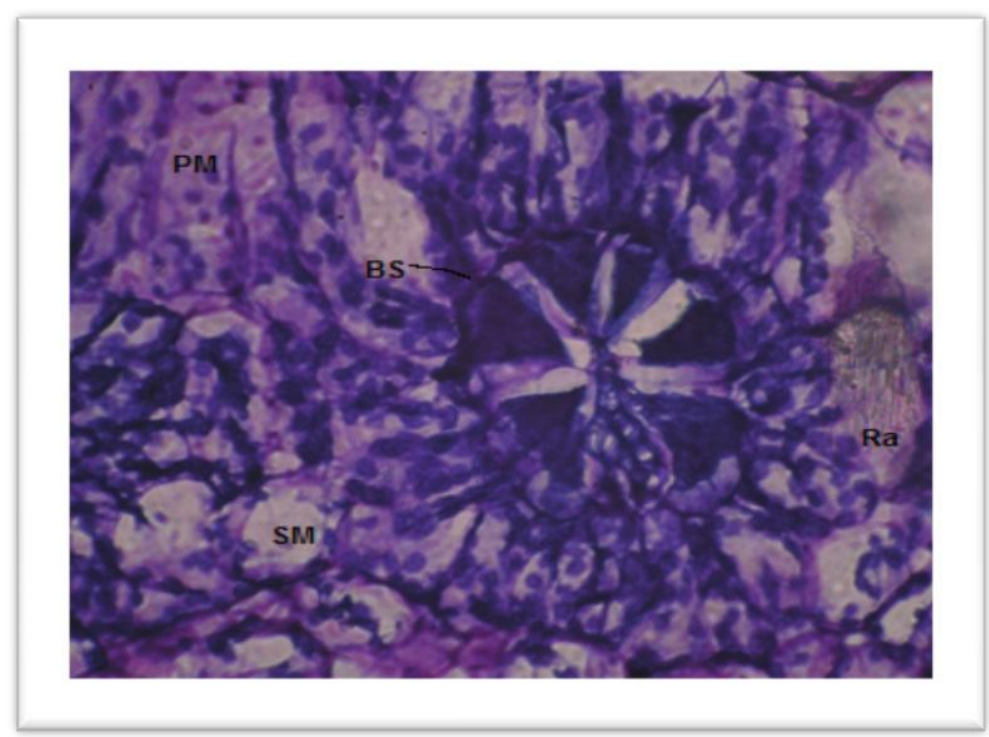

AdE-Adaxial epidermis, AdS-Adaxial side, AbE-Abaxial epidermis, PM-Palisade mesophyll, SM-Spongy mesophyll, BS-Bundle sheath cells,

\section{Ra-Raphide}

\section{Leaf Margin:-}

The marginal part of the lamina is bluntly conical and measures $300 \mu \mathrm{m}$ in thickness. The epidermal layer of the leaf margin consists of elliptical thick walled cells. The mesophyll tissue is compact and not well differentiated into palisade and spongy tissues. 
Fig 15:- T.S of Leaf margin

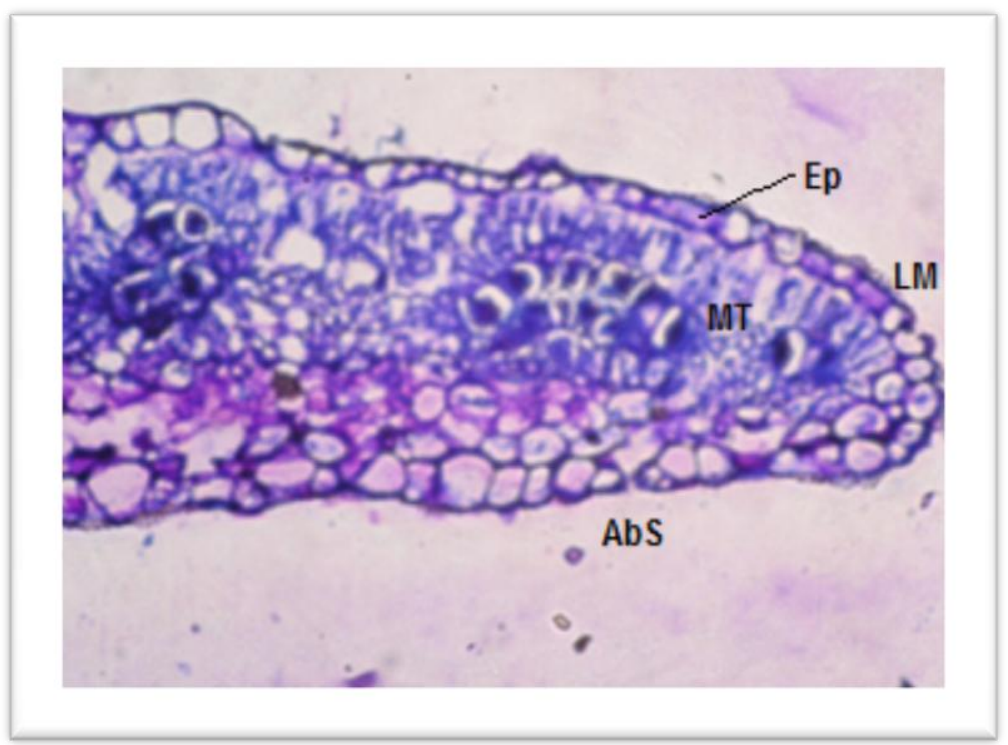

\section{Crystals:-}

Calcium oxalate crystals of raphides are abundant in the mesophyll. The raphide is a spindle shaped bundle of numerous thin pointed needles. The raphide bundle is $150 \mu \mathrm{m}$ long and $40 \mu \mathrm{m}$ thick.

Fig 16:- Raphides in the mesophyll.

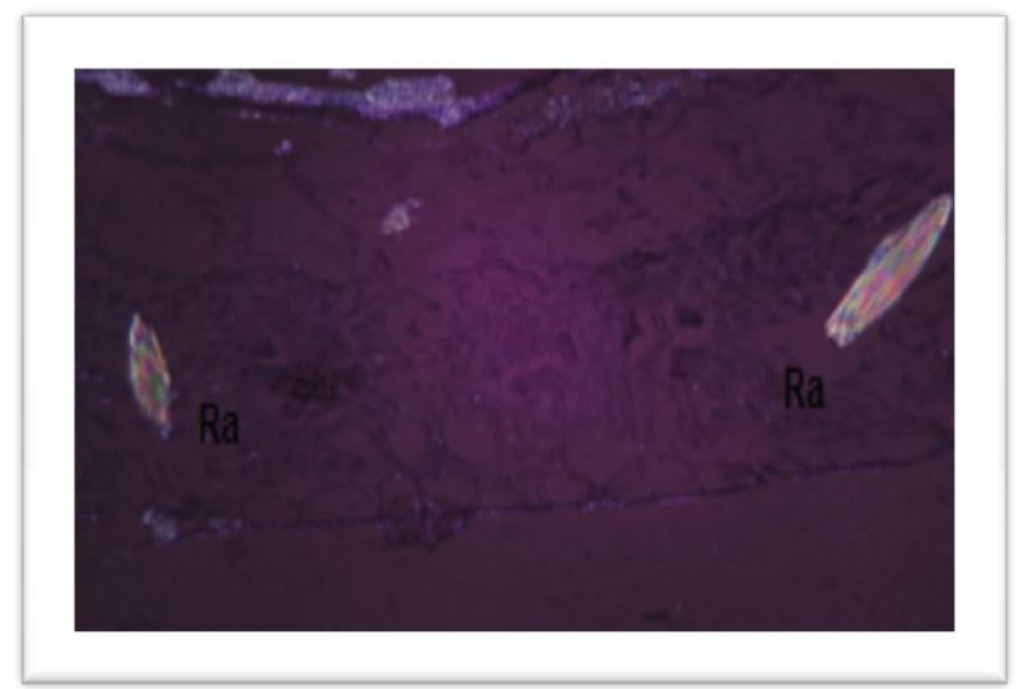

Ep-Epidermis, LM-Leaf margin, MT-Mesophyll tissue, AbS-Abaxial side, Ra-Raphide 
Fig17:- Single raphide bundle enlarged.

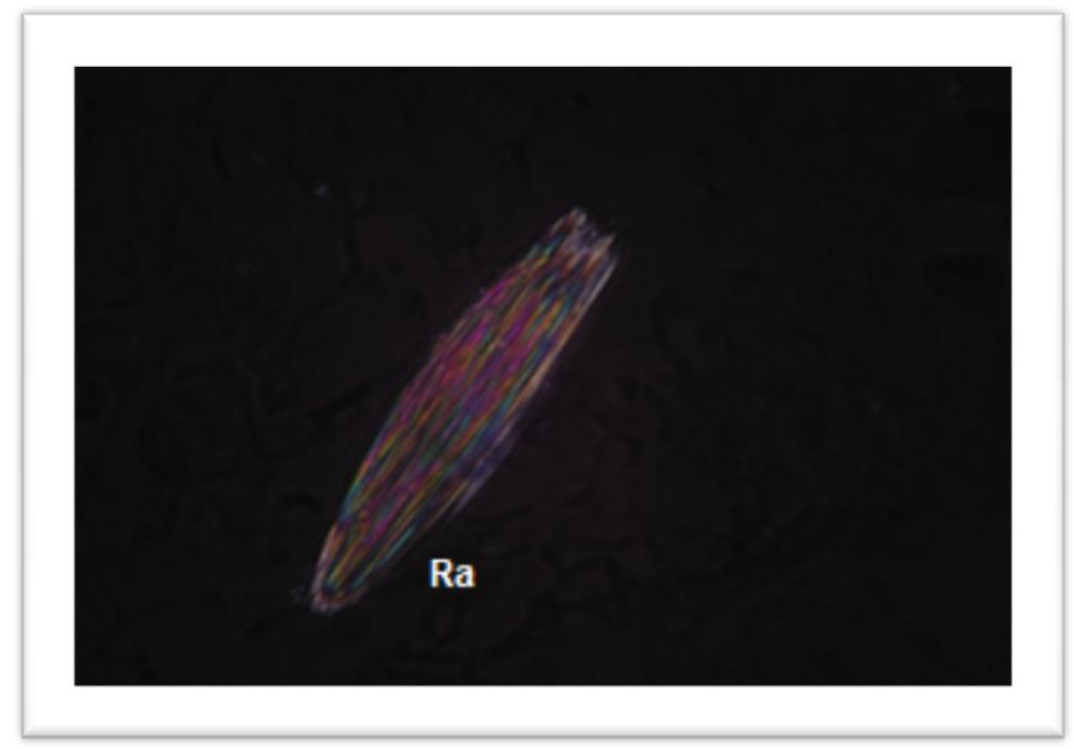

Venation of the lamina:-

The leaf consists of reticulate venation system. Primary and secondary veins are fairly thick and straight. The vein islets are wide and irregular in shape and size. The vein terminations are well developed. The terminations are mostly branched repeatedly forming dendroid outline. The terminations are thick and straight.

Fig18:- Vein islets and vein termination.

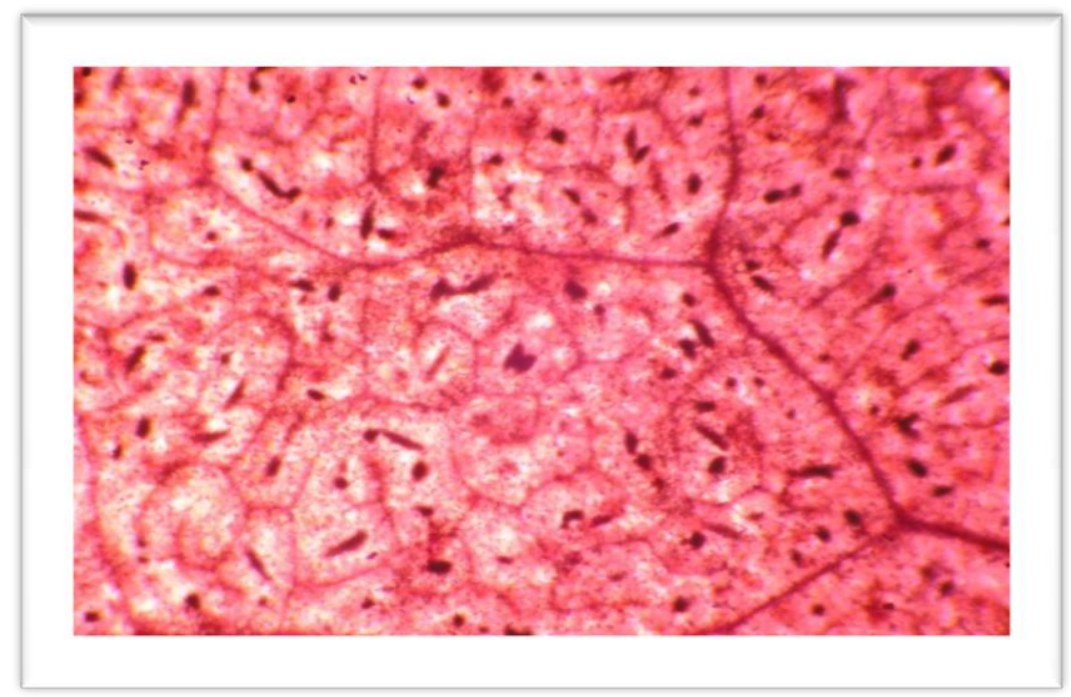

Ra-Raphide 
Fig 19:- Vein islet and vein termination with raphide distribution

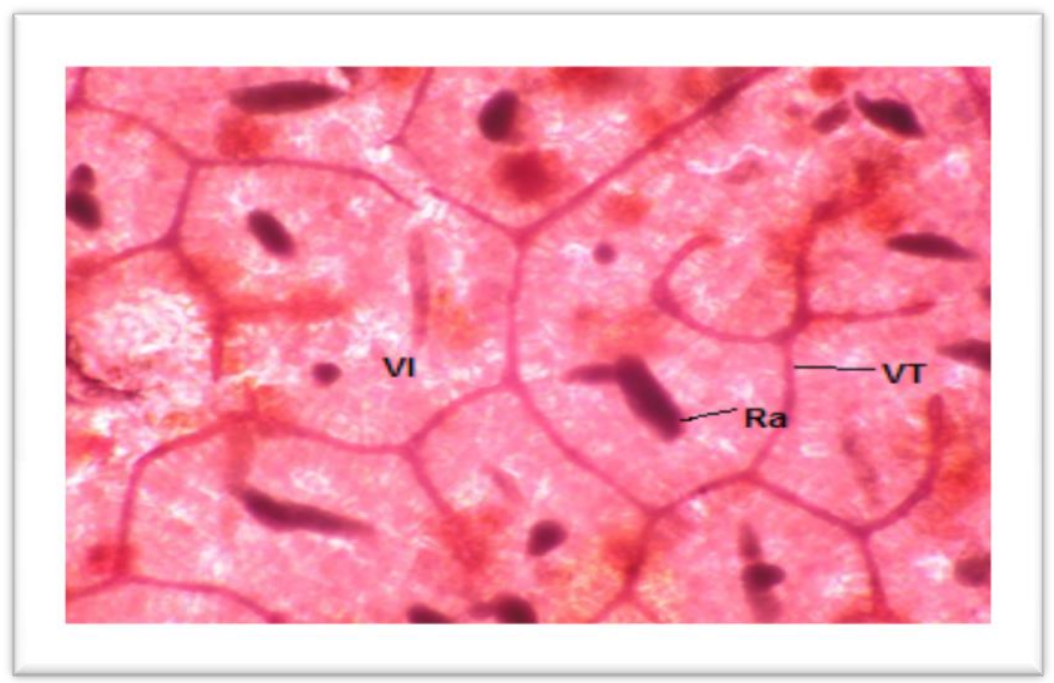

\section{Conclusion:-}

Preliminary phytochemical screening study confirmed the presence of carbohydrates, triterpenoids, glycosides, alkaloids, saponins, tannins / phenols and flavonoids in various plant extracts.

The reports (IR, NMR and Mass spectrum) which are obtained from the spectroscopic studies of the isolated compound suggested the probable structure, i.e., alkyl flavones from EEBD.

Microscopy of stem and leaves of Boerhaavia diffusa linn showed that the leaf is dorsi ventral with less prominent midrib and thick lamina. The stem exhibits unusual structure of anomalous secondary growth. It consists of central group of discrete vascular bundles called medullary bundles. The medullary bundles are surrounded by a thick continuous secondary xylem.

\section{References:-}

1. Easu K. Plant anatomy . John Wiley and Sons, New York. 1964: 767.

2. Edwin JE, Sheeja EJ. Textbook of Pharmacognosy and Phytochemistry. $1^{\text {st }}$ ed., CBS Publishers \& Distributors, New Delhi. 2009; 27.

3. Gamble KS. Flora of the presidency of Madras. Botanical survey of India, Calcutta, India. 1935.

4. Khandelwal KR. Practical Pharmacognosy. $19^{\text {th }}$ ed., NiraliPrakashan, Pune. 2008; 149-155.

5. Kokate CK, Purohit AP, Gokhale SB. Pharmacognosy. $47^{\text {th }}$ ed., NiraliPrakashan, Pune. 2012; 3.86.

6. Kumar N. A text book of Pharmacognosy. $1^{\text {st }}$ ed., AITBS publishers, New Delhi. 2010; 222.

7. Metcalfe CR, Chalk L. Anatomy of the Dicotyledons. Clarendon press, Oxford. 1979; 276.

8. Mukherjee Pulok k. "Quality control of Herbal Drug" 2nd Edition Published by "Business Horizons Pharmaceutical Publishers" page no. $379-400$.

9. Niren NS, Nayak BS. Experimental Pharmacognosy. ${ }^{\text {st }}$ ed., S.Vikas\& Co, Jalandar. 2009; 190-199.

10. Sanjay S. A text book of Pharmacognosy. $1^{\text {st }}$ ed., S.Vikas\& Co, Jalandhar. 2008; 93.

11. Vinod DR. Pharmacognosy\&Phytochemistry, part-II. $1^{\text {st }}$ ed., Career publications, Nashik. 2006; 200.

12. Yoga NSN. Medicinal plants of India. Regional research Institute, Bangalore, India. 2000; 715. 